Moore Park, Fermoy, Co. Cork, and a sheep research centre at Creagh, Ballinrobe, Co. Mayo. The Rural Economy Division will include departments of farm management, agricultural economics, agricultural marketing, rural sociology, home economics and agricultural engineering. It will provide a service for the economic evaluation of the research in other divisions and for the general management programme of the Institute's farms. An agricultural machinery testing service is being organized. The horticultural work of the Horticulture and Forestry Division will be carried out at centres dealing with glasshouse and vegetable erops, soft fruits, pomology and bee-keeping. A National Research Centre for Glasshouse and Vegetable Crops has been established at Kinsealy, Malahide, Co. Dublin. In addition, a field experimental station to cater for soft fruits has been set up at Clonroche, Wexford, and an experimental unit for pomology research at Dungarvan, Co. Waterford.

The foundation ceremony of An Foras Talúntais, commencing with religious services, was held in Dublin on May 19. The opening of the headquarters' offices of An Foras Talúntais at 33 Merrion Road, Ballsbridge, Dublin, by the President of Ireland, and the unveiling of a commemorative plaque acknowledging Unites States aid in the foundation of the Institute, took place in the afternoon.

The following officers of the Institute have been appointed :

\section{Director :}

Dr. T. Walsh

Dr. T. Walsh graduated in 1937 and was awarded a postgraduate scholarship which he held in the Soil Science Department, University College, Dublin. He took the degrees of M.Agr.Sc. in 1938, Ph.D. in 1940 and D.Se. in 1946 on published work. He was elected a member of the Royal Irish Academy in 1954. During 1938-45 he was assistant lecturer in soil science, in University College, Dublin, and during 1945-52, soils advisory officer in the Department of Agriculture. He was senior inspector in charge of soils and grassland research during 1952-58. In August 1958 he was appointed director of the Agricultural Institute. He has represented the Republic of Ireland at many scientific and agricultural conferences and is national representative on a number of committees of the Organization for European Economic Co-operation and the United Nations Food and Agriculture Organization. $\mathrm{He}$ was responsible for building up research facilities in soils and grassland research in the Department of Agriculture, especially at Johnstown Castle Agricultural College. Dr. Walsh has specialized in pedology, soil fertility, plant nutrition, and more recently in grassland husbandry with particular reference to the soil fertility - animal nutrition aspects of this subject, and has published some seventy scientific papers.

\section{Chief of the Animal Production Division : \\ Dr. L. B. O'Moore}

Dr. Laurence Butler O'Moore, who has been appointed ehief of the Animal Production Division, took the degrees of M.R.C.V.S, at the Veterinary College in 1945, M.Se. at the University of Dublin for a thesis on the "Physiology of Reproduction" in 1946, and Ph.D. at the University in 1950 for a study on "Phosphorus Deficiency in Grazing Cattle". Since 1948 he has been on the staff of the Veterinary Research Laboratory, Department of Agriculture, where he held the post of superintending senior research officer with responsibility for research dealing with biochemistry, vaccine production and calf diseases. Dr. O'Moore is a well-known authority in the fields of animal biochemistry, physiology and nutrition. His work on nutritional deficiencies and metabolic disturbances in animals at pasture is especially well known, his reputation in this particular sphere being world-wide.

\section{Chief of the Rural Economy Division :}

Mr. J. J. Byrne

Mr. James J. Byrne, who has been appointed chiof of the Rural Economy Division, was educated ot: St. Kieran's College, Kilkenny, and the National University, and graduated in law, politics and economics in 1940 , being awarded a postgraduate scholarship. He took the M.A. (Economics) degree at the National University in 1941 , being awarded a travelling studentship with which he proceeded to the University of Cambridge, where he was awarded the M.Sc. (Economics) degree in 1944, taking the LL.B. (National University of Ireland) in the same year. In 1946, Mr. Bryne became lecturer in economies in the University of Dublin, where he was appointed registrar of the Schools of Agrieulture and Veterinary Medicine in 1955, and secretary of the Management Committee of the Kells Ingram Farm in 1957. During 1948-54, in addition to his duties in the University of Dublin, he was secretary of the Population Commission, and this work brought him into particularly close touch with the main national social problems. Mr. Byrne takes up his new post with an international reputation in the sphere of researeh in economics.

\title{
BRITISH MAMMALS AND SOME OTHERS
}

$\mathrm{A}^{\mathrm{N}}$ $\mathrm{N}$ appreciable number of important papers were produced on a variety of subjects during the conference of the Mammal Society of the British Isles, which was held at Bristol during April 6-9. Miss J. Shillito (University of Exeter) described her findings on the population structure, ecology and breeding of the common shrew (Sorex araneus) under wild conditions: her observations showed much movement of juveniles before their breeding territories were established, the range covered by the males being rather greater than that by the females.
The various invertebrates consumed by shrews were also examined and listed. The other insectivore investigated was the water shrow (Neomys fodiens bicolor). P. A. Jewell and A. E. Hawkins (Roval Veterinary College) had shown that the normal diet of this shrew had an exceedingly low calorific value, so that the great physical activity employed in the search for food was associated with a resting metabolic rate at least as low as that of a mouse fed on the same standard diet. The Earl of Cranbrook pointed out that the saliva of this shrew was prob- 
ably toxic, since worms bitten by the animal appeared to be paralysed.

The food of the water vole (Arvicola amphibius), dormouse (Muscardinus avellanarius) and harvest mouse (Micromys minutus) was discussed by $M$. Knight and their individual preferences noted. Small mammals had been studied in the wild in two localities. R. M. Newsom (Bureau of Animal Population) at Wytham had followed the population fluctuations in the bank vole (Clethrionomys glareolus), field vole (Microtus agrestis) and wood mouse (Apodemus sylvaticus) over some sixteen months. The results of trapping and marking showed that although breeding of all three species ceased normally during the winter of $1957-58$, they all continued to breed in the woodland during the winter of 1958-59. Work on the small mammals of South Rona was carried out by W. O. Copland and M. J. Delany (University of Southampton), who trapped for six days during August 1958. Small mammals proved very scarce, and only wood mice (Apodemus sylvaticus) and the common and pigmy shrews (Sorex araneus and $S$. minutus) were found. M. J. Delany had further compared the specific characters in Apodemus sylvaticus from the Scottish mainland with large series from Mull and Lewis, and found that these island races only differed from the mainland one in size: he therefore concluded that there was no justification for considering Apodemus hebridensis as a distinct species. With $\mathrm{S}$. Krishnaswamy and K. A. Munday (University of Southampton), he has used filter-paper electrophoresis on blood serum from various murids, and this method has shown that the pattern from the island race of Apodemus differs from that of $A$. sylvaticus but is closely akin to that of A. flavicollis.

Among larger mammals, J. E. C. Flux (University of Aberdeen) had investigated the colour change in wild specimens of the mountain hare (Lepus timidus scoticus) in Aberdeenshire. The order in which moulting occurred in different parts of the body was noted and it was found that the spring moult took place much less abruptly than the autumn one. G. F. Moysey showed an electrical device using a spring switch which he had used to obtain automatic records of badgers moving in and out of their setts; preliminary results gave fluctuations in the period of nocturnal activity near and far from the sett, which might be correlated with seasonal changes in badger behaviour.

Roe deer (Capreolus capreolus) were touched upon by two members. D. Stephen made observations extending the calving season. He also commented upon the absence of the stage of production of buttons by two young bucks kept by him, as a preliminary to the formation of the first antler spikes. F. J. Taylor Page discussed the activity of mature bucks in fraying young trees as a territorial demarcation. With T. J. Pickvance (University of Birmingham), he also described methods of carrying out region mammal surveys, with particular reference to those being carried out at present in the midlands and in Norfolk.

The problem of erosion outside Britain was dealt with by H. V. Thompson, who spoke on the rabbit (Oryctolagus cuniculus) in Australia and New Zealand, while O. Hook and H. N. Southern (Bureau of Animal Population) spoke of similar problems caused by the very large number of hippopotami in Uganda. Control methods are being used against both these species. Other foreign species came under review when Prof. K. Zimmermann (Berlin) spoke about rodents which he had collected in China, and which in some cases had been brought back alive to Berlin. H. Bohlken (Kiel) gave an account of his findings on the stomachs of the tylopoda and showed that there were important differences between those of tylopods and ruminants; this suggested that the faculty of rumination differs between these two groups and has been acquired twice over in the phylogenetic history of the artiodactyla. J. F. D. Frazer

\section{STRUCTURAL EFFECTS OF KINETIC HEATING}

$\mathrm{O}^{\mathrm{x}}$ $\mathrm{N}$ April 21 an all-day discussion on "The Structural Effects of Kinetic Heating" was held by the Royal Aeronautical Society at the Institution of Mechanical Engineers.

The chair was taken by Mr. M. B. Morgan (deputy director, Royal Aircraft Establishment, Farmborough). In his opening remarks, he said that although the effects of kinetic heating had been pioneered by engine manufacturers, it was a comparatively new field for the structural designer of to-day. In the future, kinetic heating effects would have to be taken into account in the design of very high-speed aircraft and missiles, so that the designer would have to become familiar with the scientific background to the problem.

The first paper, "Some Factors affecting the Choice of Materials", was read by Mr. W. G. Heath (A. V. Roe and Co., Ltd.). He opened with the assumption that certain fundamental parameters were outside the control of the structures designer. The designer must study the effect of these factors on suitable materials, considering not only structural efficiency, stiffness, creep, fatigue and thermal stress but also the availability of the materials and the ability of the workshops to handle them. He showed curves giving a comparison of some of the materials available at the present time--aluminium alloys, titanium alloys and steels--which are suitable for structures operating at temperatures up to $500^{\circ} \mathrm{C}$. Later, brief mention was made of materials suitable for use at higher temperatures. He urged every designer to throw away the curves, which he felt sure they all had, of specific strength plotted against temperature, as compression structure efficiency could not be determined from them, and they could be misleading even for tension structures. Mr. Heath showed curves of 'specific stability' parameters which he had derived. He felt that these would be helpful in the choice of the most efficient material for short-life compression structures. He stressed the need for more information concerning the effects of creep, fatigue and thermal stress on long-life structures, and the difficulty in obtaining satisfactory experimental results - a point in favour of 'fail-safe' design. 